\title{
Organization Factors That Influence Transfer of Training among Employees at Farmers' Organisation Authority (FOA) Headquarters, Kuala Lumpur
}

\author{
Roshidah Ahmada*, Khulida Kirana Yahya ${ }^{b}$ \\ a Lembaga Pertubuhan Peladang (LPP), Menara LPP, Jalan Sultan Salehuddin, 50480 Kuala Lumpur, Malaysia \\ ${ }^{b}$ School of Business Management, Universiti Utara Malaysia, 06010 UUM Sintok, Kedah, Malaysia \\ *Corresponding author: roshidah@lpp.gov.my
}

Article history: Received 25 February 2019 Received in revised form: 05 April 2019 Accepted: 28 May 2019 Published online: 29 August 2019

\begin{abstract}
Transfer of training is important to organisations as they have devoted lot of money to send their employees for training to increase the employees' knowledge, skills and abilities. This paper examines the relationships of rewards, supervision, and peer relationship on the transfer of training involving employees at FOA Headquarters, Kuala Lumpur. Self-administered questionnaires were adapted from various sources and consisted of items related to transfer of training, rewards, supervision and peer relationships. A total of 344 questionnaires were distributed but only 265 were returned and used for further assessment. This study applied descriptive statistics, reliability and inferential analysis to examine the relationships among the variables. The results showed that only rewards and supervision had significant relationship with transfer of training while peer relationship was found to be insignificant.
\end{abstract}

Keywords: Transfer of training; rewards; supervision; peer relationships

\begin{abstract}
Abstrak
Pemindahan latihan adalah penting terhadap sesebuah organisasi kerana sesebuah organisasi memperuntukkan jumlah yang besar bagi menghantar kakitangannya untuk menjalani latihan atau kursus demi meningkatkan pengetahuan, kemahiran dan kemampuan mereka. Tujuan penyelidikan ini adalah untuk mengkaji sejauh mana ganjaran, penyeliaan, dan hubungan sesama pekerja mempengaruhi proses pemindahan latihan di Ibupejabat Lembaga Pertubuhan Peladang (LPP), Kuala Lumpur. Soalan kaji selidik diadaptasi daripada pelbagai sumber mengandungi pemboleh ubah berkaitan dengan pemindahan latihan, ganjaran, penyeliaan dan hubungan rakan sekerja. Sebanyak 344 soal selidik diedarkan tetapi hanya 265 dikembalikan dan digunakan untuk kajian. Kajian ini menggunakan statistik deskriptif, kebolehpercayaan dan analisis inferens untuk mengkaji hubungan antara pembolehubah. Keputusan menunjukkan bahawa hanya ganjaran dan penyeliaan mempunyai hubungan yang signifikan dengan pemindahan latihan manakala hubungan rakan sekerja didapati tidak signifikan.
\end{abstract}

Kata kunci: Pemindahan latihan; ganjaran; penyeliaan; hubungan rakan sekerja.

(C) 2019 Penerbit UTM Press. All rights reserved

\subsection{INTRODUCTION}

There are continuous divisions of training in many organisations. This training division guarantee the quality assurance of every staff employed by the organisations. Failure to have quality employees will result in failures in the organisation performance. The transfer of training can be characterized as the level where all the individuals were capable of utilizing the knowledge, skills and ability on the job that were gained in a training programme (Daley, 2012). It is crucial for organisations to provide Continuing Professional Development (CPD) to ensure the employees are at their top performances consistently. Besides, CPD can be an important factor in developing quality employees. CPD can increase job satisfaction, job quality, update knowledge and skills as well as future professional growth in their companies. The competencies of employees depend on the transfer of training received during CPD.

Quendler and Lamb (2016) identified the issues in obtaining the transfer of training skills and ability. Training programmes that are ineffectively planned and sorted can cause undesirable results. Therefore, it is important for every training manager to ensure they have authority and an effective in enhancing the workers' performance.

Although, FOA requires training and development programmes to achieve its goals as these goals symbolise the organisation plans. Continuous learning is crucial in FOA because the transfer of information and skills can develop employees in the organisation. Measuring success of a training and development programme depends on the level of knowledge, skills and behaviour which can be acquired and implemented to increase productivity, enhance the works' efficiency and achieve the goals of the organisation (Sanghi, 2016; Khulida \& Yean, 2015).

Therefore, it is essential for employees of FOA to attend training programmes to encourage them and to benefit from these programmes. The employees can choose the types of training they want to attend which are related to their jobs. In addition to the liberty of picking the types of training that they want to attend such as high self-confidence level, career demand and positive attitudes can also motivate these 
employees to get more knowledge (Bakker, 2012). Consequently, if the knowledge and skills can be used and applied in the workplace, the transfer of training is considered successful. Workers who did not attend training can acquire the skills from those who attended training courses. Therefore, it is crucial for employer to train its new employees.

Meanwhile, Malaysian government realizes the importance of training and development of human resources for the nation's development. The government implements the Human Resource Development Fund (HRDF) Act to serve mandatory statutory requirement for any qualified training provider to give training to their workers (Pilz, 2016). The Public Service Department spent RM4.9 billion to train public sector employees to achieve a knowledge-based workforce in 2017 (Professional Bulletin, 2017).

However, according to the administration of FOA, there have been complaints about the quality of employees who were sent for training (LPP, 2014). The higher management noticed an element that can be improved. Thus, FOA needs to design and develop quality programmes to enhance employees' performance.

Based on studies on transfer of training by Govaerts, Kyndt, Vreye and Dochy (2017), there was lack in studies on the roles of work environment (supervisor support and reward) and the trainees' characteristics (organization commitment and job involvement) in the transfer of training. The available studies that discussed the transfer training ignored the role of the work environment and the trainees' characteristics (Huang, Ford \& Ryan, 2017).

Therefore, this study will focus on improving transfer of training through supervision, rewards and peer relationships to increase the performance of employees (Xiao, 1996). Due to the lack of studies on the above variables, this study will look into the relationship among variables affecting employees' performance supervision, rewards and peer relationships.

\subsection{LITERATURE REVIEW}

\section{Transfer of Training}

Training transfer involves on the orientation of knowledge, trained expertise as well as the sustainment of trained assistances and the length of programmes (Vikas, 2016). Training transfer is one of the important elements in improving training efficiency standards and increasing organisational performance (Miller, 2016).

Xiao (1996) defined transfer of trainings the employee's skill to improve the refined skills in training and relating it into the job which resulted to work more proficiently. Human resource researcher (Bhatti, 2013) found that transfer of training has been solitary of the basic features in the training effectiveness that will encourage the employees as well as the organisation performance. They deliberate on the issues of training effectiveness and consider that there are many factors which affect transfer of training.

Most organisations spend millions each year on training, yet only a small portion of that investment results in improved performance. It is important to ensure the training transfer among participants especially when it involves important individuals or groups (Ismail, 2016). These important individuals include managers, peers, customers and the employers. Stakeholders also assume accountability for supporting training transfer. The objective of training is not only to improve their knowledge and skills but also to transfer learning into performance, which in turn leads to enhancements in organisation results. Training transfer is not an event; it is a dynamic and complex process. Careful training analysis (planning) is needed to ensure smooth transfer of knowledge, skills and attitude. Employers need to carefully measure the effectiveness of training.

Xiao (1996) expresses that by providing training which addresses the worker's issues, the organisation can create more optimistic outcome from them. Moreover, employees can improve their work performances through regular use of the knowledgeable skills and knowledge guidance gained from the training they attended (Dmytriv, 2015).

\section{Rewards}

Rewards are frequently used as an encouragement to achieve greater effort when it comes to distinct performance, to encourage and engage workers to strive beyond work tasks (Khulida \& Yean, 2015). According to Koen, Asada, Nixon, Rahuman and Arif (2017), reward is an advantage achieved for performing a task, rendering a service. In general, the major reward is a pay. Beside pay, common rewards package in Malaysia are bonus, pension scheme, pay insurance, company cars, loans and share options.

This is mostly accepted by organisations as a vital factor in encouraging workers. Organisations all over the world continuously look for innovative ways to make their rewards more meaningful to their workers so that the latter can endure to constrain themselves to their jobs and to the organisation (Mattarelli \& Tagliaventi 2015). Reward has always been perceived to be an essential factor in worker performance from the management perspective (Barrick, Thurgood, Smith and Court right, 2015). Foss, Pedersen, Reinholt, Fosgaard and Stea (2015) consider reward as one of the major instruments for motivating workers in training organisations. It is also used to attract employees in the organisations.

Furthermore, a good reward system should raise the workers' incentives as it motivates individual employees (Montalvo, 2018). It also indicates that in order to encourage transfer of training, the reward system must consider goals and feedbacks. Moreover, reward system should have stressed on different duties and result-based incentives (Elwyn, Frosch \& Kobrin, 2015). Becker (2016) states that rewards are remarkable in motivating positive attitudes and behaviours among staff members. Bhatti (2016) points out that rewards play a vital role in keeping the workers away from any possible de-motivation experiences. Employees in organisations can show their increased knowledge and skills by utilising these skills at their workplace (efforts, approaches and behaviours).

In other words, rewards can be used by the organisation as an instrument to drive workers to improve their efforts and behaviours as well as to eradicate any unwanted behaviours (Bammens, 2016). By using an appropriate reward, it helps organisations to make their employees becomes better and more engaged. They will become more engaged employees with confident attitudes in their organisations. The findings of this study indicate the appreciation of rewards which affect the transfer of training. Therefore, based on the above discussion about rewards and transfer of training, the following hypothesis is proposed:

H1: There is a relationship between rewards and transfer of training. 


\section{Supervision}

Supervision can be defined as the act of helping their workers to show their knowledge, skills and attitudes gathered from the training programmes (Fang \& Wu, 2015). According to Massenberg, Spurk and Kauffeld (2015), supervision plays an important role in training effectiveness. Without getting support from supervisors, the transfer of training method cannot be effective. This is because the workers tend to lose attention when they are not monitored or supervised. Supervision are considered to be one of the most powerful tools in improving transfer of training by numerous studies (Melby-Lervag, Redick \& Hulme, 2016).

Chelliah, Bujang, Lew and Adriel (2016) strain on the part of supervisors in influencing the transfer of training. The simple basics of supervision entail identifying job tasks, setting goals, providing feedback, procuring on commitment and giving support (Musundire, 2015). Lipsham, (2016) describes supervision as a practice by which a research student is directed and permitted to gain techniques, methods in research without distracting or misleading the supervisee's own intellectual improvement.

Furthermore, Anjah (2017) states that supervision is an interference that is delivered by a senior member of a profession to a junior member or members of that profession (supervisee) as it can rise workers willingness to transfer the information to their work. Employee willingness is imperative to make the transfer of training process occur at the workplace. Thus, the targeted aims and outcomes can be achieved, for instance, increase knowledge, skills and abilities. Liu, Zhang, Liao and Hao (2016), originate that supervision shows a dynamic role on transfer of training in organisations. Chelliah, Bujang, Lew and Adriel (2016) commend that the possibility to which the supervisor executes in ways to consistent with the training has a significant influence on the transfer of training. The basic elements of supervision comprise of identifying job tasks, setting goals, providing feedback, procuring commitment and giving support (Musundire, 2015).

Additionally, Hughes (2016) reveals that supervision can direct clear suggestions regarding the roles and ethics of training, progress, and proficiency growth. Supervision in the organisations can also motivate employees to perform in their organisations. In other words, positive outcomes from training programmes will be achieve when supervision is involved at the first stage of the training implementation. Therefore, the following hypothesis is proposed for this study:

$\mathrm{H} 2$ : There is a relationship between supervision and transfer of training.

\section{Peer Relationships}

Peer relationships are an approach for individuals to come together with collective experiences to change an uncooperative arrangement and moving beyond their perceived boundaries through humble and equally relationships (Hernandez, 2017). Thus, peer relationships can be a passionate relationship, frequently involved with prominent supports that are mutually obtainable or delivered by individuals. The mostly understood as the co-employees' encouragement to use new knowledge and ability in organisations are peer relationships (Mbachu \& Bizien 2017). It has a significant impact on the training transfer (Munro, 2017) and they affect transfer of training including setting applied ideas, giving support or contributing positive feedback (Alnowaiser, 2017). Schindler and Burkholder (2016) found that peer relationships among managerial factors has more influence on past training performance and motivation with regard to transfer of training. Meanwhile, the study carried out by Chauhan, Ghosh, Rai and Shukla (2016) reveal that peer relationships have influence on transfer of training.

Peer relationships are more concentrated in supporting the use of knowledge at workplace (Mbachu \& Bizien 2017). Chiaburu (2016) in his study shows that peer relationships were more significant than worker-supervisors' relationships in organisations. The role played by peers is to set goals with their friends. Moreover, peers also achieve as supporters to their age group. It indicated that peers will contribute positive comments and feedback to their colleagues at their workplace. In the form of feedback, peer relationships are very essential in determining employees' ability to relate what they have gain at workplace (Mbachu \& Bizien 2017). This is in line with the study done by Capaldo, Depolo, Rippa and Schiattone (2017) who institute that peer relationships have a better influence on past training behaviours and motivation to transfer of training.

Furthermore, peers also perform as assistants to their colleagues. It can be stated that peers will contribute positive comments and feedback to their colleagues at the workplace. In the form of feedback, peer relationships are very essential in determining workers' ability to relate with what they had learned of the work. Chiaburu (2016) also noted that the different nature of private sector organisation in India which might involve different cultures, environments and high competitiveness. Therefore, the following hypothesis is proposed for this study:

H3: There is a relationship between peer relationships and transfer of training.

The Conceptual framework for the study is as indicated in Figure 1 below.

IV

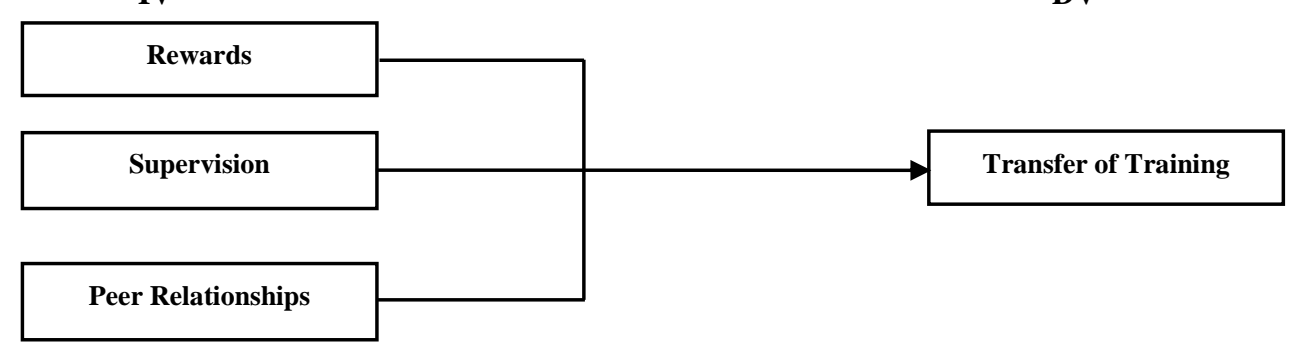

Figure 1 Conceptual framework 


\subsection{RESEARCH METHODOLOGY}

\section{Measurements}

The questionnaires comprised of items to measure transfer of training, supervision, rewards and peer relationship. The instrument was adopted from Xiao, (1996). Six items were used to measure the transfer of training and supervision, respectively. Meanwhile, 7-items were adopted from Xiao, (1996) also to examine rewards. Peer relationship was measured by 5-items that gathered from Pabon and Gurin, 1992.

Data Analysis and Results

Data collected were entered and coded using Statistical Package for Social Science (SPSS) software version 22.0. A total number of 344 questionnaires was distributed to employees in FOA Headquarters, Kuala Lumpur but only 265 set of questionnaires were returned and used for further analyses. A total of 344 hard copies of questionnaires were distributed to professional and management as well as supporting staff. The Chief Clerks from eighteen departments collected the 265 questionnaires, which represent a response rate of $77 \%$.

\section{Profiles of Employees}

Based on table 1, majority of the respondents $144(57.1 \%)$ were between the age of 30-39, while only 18 (7.1\%) were 50 years and above. Based on the findings, many of the FOA employees were between the ages of 30-39 namely Gen-Y. Gen-Y is known as Millennial and was born between early 1980s to early 2000s (Lyons \& Kuron, 2014). Besides, Gen-Y would choose and hope their managers to take care of their well-being (Bolton, 2013). Moreover, Gen-Y is more effective in certain fields like multitasking, responding to visual stimulation and filtering information. However, they are less experience in dealing with face-to-face interaction and translating non-verbal clues (Rani \& Samuel, 2016). It is because these generations have been exposed to computers, laptops and other technological effects since at a young age.

In terms of gender, $150(59.5 \%)$ were female, while $102(40.5 \%)$ were male. For the job categories, 165 (65.5\%) were supporting staffs while only $87(34.5 \%)$ were professional and management staffs. The highest academic achievement were 89 (35.3\%) had STPM while $81(32.1 \%)$ had Diplomas.

Referring to the tenure in organisation at FOA, 112 (44.4\%) had served between 1 to 3 years, 66 (26.2\%) had served more than 10 years in FOA while $44(17.5 \%)$ had spent 4 to 6 years in FOA. In addition, $176(69.8 \%)$ had attended training programme more than $1-3$ times while $69(27.4 \%)$ attended in training programme up to 4 to 6 times.

Table 1 Demographic profile of respondents

\begin{tabular}{|c|c|c|c|}
\hline \multicolumn{2}{|l|}{ Demographic characteristic } & \multirow{2}{*}{$\begin{array}{c}\text { Frequency } \\
102\end{array}$} & \multirow{2}{*}{$\begin{array}{c}\text { Percentage (\%) } \\
40.5\end{array}$} \\
\hline Gender & Male & & \\
\hline & Female & 150 & 59.5 \\
\hline \multirow[t]{4}{*}{ Age } & Below 29 & 38 & 15.1 \\
\hline & $30-39$ & 144 & 57.1 \\
\hline & $40-49$ & 52 & 20.6 \\
\hline & 50 years above & 18 & 7.1 \\
\hline \multirow[t]{2}{*}{ Grade } & Professional and & 87 & 34.5 \\
\hline & Supporting staffs & 165 & 65.5 \\
\hline \multirow[t]{5}{*}{ Highest qualification } & SPM & 19 & 7.5 \\
\hline & STPM & 89 & 35.3 \\
\hline & Diploma & 81 & 32.1 \\
\hline & Ijazah & 35 & 13.9 \\
\hline & Masters & 28 & 11.1 \\
\hline \multirow[t]{5}{*}{ Salary } & Less than 2000 & 14 & 5.6 \\
\hline & $2001-4000$ & 165 & 65.5 \\
\hline & $4001-6000$ & 67 & 26.6 \\
\hline & 6001-8000 & 6 & 2.4 \\
\hline & $8001-10,000$ & 0 & 0 \\
\hline \multirow[t]{6}{*}{ Tenure } & Less than a year & 13 & 5.2 \\
\hline & $1-3$ years & 112 & 44.4 \\
\hline & 4-6 years & 44 & 17.5 \\
\hline & $7-10$ years & 17 & 6.7 \\
\hline & Above 10 years & 66 & 26.2 \\
\hline & None & 6 & 2.4 \\
\hline \multirow[t]{4}{*}{ Training programmes attended/year } & $1-3$ times & 176 & 69.8 \\
\hline & $4-6$ times & 69 & 27.4 \\
\hline & $7-10$ times & 1 & 0.4 \\
\hline & Above 10 & 0 & 0 \\
\hline
\end{tabular}




\subsection{FINDINGS}

The results of the correlation (Table 2) indicated that the three variables have significant relationship with transfer of training. Transfer of training and supervision indicate a positive correlation of $(r=0.399 ; \mathrm{p} \leq 0.05)$. Likewise, transfer of training and peer relationships have a positive significant correlation at $(r=0.104 ; \mathrm{p} \leq 0.05)$. Similarly, reward have significant correlation with transfer of training at $(r=0.445$; $\mathrm{p} \leq 0.05)$. The result are shown in Table 2 .

Table 2 Pearson correlation analysis of the variables

\begin{tabular}{llllll}
\hline No. & Variables & 1 & 2 & 3 & 4 \\
\hline 1 & Transfer of training & 1 & & & \\
2 & Supervision & $.399^{* *}$ & 1.00 & & \\
3 & Rewards & $.445^{* *}$ & $.389^{* *}$ & 1.00 & \\
4 & Peer relationships & $.104^{* *}$ & $.205^{* *}$ & $.509^{* *}$ & 1.00 \\
\hline & & $* * \mathrm{p} \leq 0.01$ level (2-tailed); ${ }^{*} \mathrm{p} \leq 0.05$ level (2-tailed)
\end{tabular}

Regression analysis is conducted on the three independent variables. This is to determine if there is significant relationship with the variable. The results are shown in Table 3. From the regression result, the value of $R^{2}$ was 0.279 meaning that the independent variable (supervision, rewards and peer relationships) explains $27.9 \%$ variability on transfer of training. From the regression analysis, it was found that supervision $(\beta=0.267, p \leq 0.05)$ and rewards $(\beta=0.426, p \leq 0.05)$ have significant influence on transfer of training. The results revealed that with the standardized beta value of supervision $(\beta=0.267)$ and rewards $(\beta=0.426)$ are significant in influencing transfer of training compared to peer relationships $(\beta=-0.168)$.

Table 3 Multiple regression analysis of independent variables on transfer of training

\begin{tabular}{|c|c|c|c|c|c|}
\hline \multirow[t]{2}{*}{ Model } & \multicolumn{3}{|c|}{$\begin{array}{l}\text { Unstandardized Coefficients } \\
\text { Std. Error }\end{array}$} & & \multirow{2}{*}{$\begin{array}{c}\text { standardized } \\
\text { Coefficients } \\
\text { Sig. }\end{array}$} \\
\hline & $\beta$ & & beta & $\mathrm{t}$ & \\
\hline Constant & 1.562 & .310 & & 5.032 & .000 \\
\hline Supervision & .292 & .064 & .267 & 4.569 & .046 \\
\hline Rewards & .505 & .079 & .426 & 6.399 & .000 \\
\hline Peer relationships & -.189 & .071 & -.168 & -2.674 & .008 \\
\hline
\end{tabular}

\subsection{DISCUSSION AND CONCLUSION}

The results reveal that the relationship among three independent variables namely rewards, supervision and peer relationships on transfer of training among FOA employees and it aims to identify the relationship between rewards on transfer of training, to determine the relationship between supervision on transfer of training and to examine the relationship between peer relationships on transfer of training.

This training policy needs to consider implementing Corporate Social Responsibility (CSR) for Gen-Y in order to promote their involvement with farmers and employees. Transfer of training involving CSR can certainly promote positive relationship among peers. Improving reward through CSR programmes include giving awards or certificates at the FOA Monthly Assembly in order to raise their spirits and get recognition.

Results show that quite a number of supporting staff members who had experiences and worked there for more than 5 years. This group of workers should be utilized by the organisation. The management has already set up the mentor-mentee programme in the workplace whereby the experienced workers are selected as mentors (possess knowledge and skill) to the younger workers. The mentormentee programme enables the sharing of knowledge at the workplace. At the same time, when the workers attended training, they gain new ideas and can assimilate the new ideas with knowledge shared by the experience workers. Therefore, chances for the transfer of training to occur at the organisation are higher because of the positive interactions between them. The positive communications will improve the transfer of training to occur at the workplace. Equally a result, the workplace gets the expected results from the training that returns on investment.

This research was conducted to examine if training, compensation and peer influence the transfer of training in FOA. The findings provide a better understanding of the relationship from the correlation and regression analysis performed, it was found that two variables (rewards and supervision) have significant and positive relationship on transfer of training in the organisation. Although, rewards were found to be the most significant among the three variables that influence on transfer of training. Besides, the significant results help the hypotheses in this study to be accepted.

It is found that Gen-Y in FOA is lack of quality and teamwork. FOA needs to focus on the Gen-Y by focusing training on group teamwork to substitute a sense of belonging in organisation. Among the recommendations are Ministry of Agriculture and Agro-Based (MoA) as stakeholders need to increase the budget, FOA Board Members needs to include the evaluation of training programmes and FOA needs to strengthen existing training policies and provide training need analysis for each employee. It is hoped that the present study will bring more consideration to researchers worldwide to study other features such as comparison between public sector and private sector, comparison between state level and Headquarters as well as comparison between Headquarters of FOA and other agencies of similar sectors (agriculture) at Headquarters. 


\section{References}

Alnowaiser, A. (2017). The Impact Of Work Environment, Individual Characteristics, Training Design And Motivation On Training Transfer To The Work: The Case of Saudi Arabian Public Security Organisation (Doctoral dissertation, University of Westminster: London,UK).

Awais Bhatti, M., Ali, S., Isa, M., Faizal, M., \& Mohamed Battour, M. (2014). Training Transfer And Transfer Motivation: The Influence Of Individual, Environmental, Situational, Training Design, And Affective Reaction Factors. Performance Improvement Quarterly, 27(1), 51-82.

Bakker, A. B., Tims, M., \&Derks, D. (2012). Proactive Personality And Job Performance:The Role Of Job Crafting And Work Engagement. Human Relations, 65(10), $1359-1378$.

Bammens, Y. P. (2016). Employees' Innovative Behavior In Social Context: A Closer Examination Of The Role Of Organizational Care. Journal of Product Innovation Management, 33(3), 244-259.

Barrick, M. R., Thurgood, G. R., Smith, T. A., \&Courtright, S. H. (2015). Collective Organizational Engagement: Linking Motivational Antecedents, Strategic Implementation, And Firm Performance. Academy Of Management Journal, 58 (1), 111-135.

Becker, D. B. (2016). The Relationships Between Self-Efficacy, Effective Leadership/Supervision And Work Performance (University Of The Witwatersrand, Johannesburg, South Africa: Doctoral dissertation). RetrievedFrom:http://wiredspace.wits.ac.za/jspui/bitstream/10539/20613/1/Becker\%20David\%20Bernard._The\%20relationship\%20between\%20sel.pdf

Bolton, R. N., Parasuraman, A., Hoefnagels, A., Migchels, N., Kabadayi, S., Gruber, T.,\&Solnet, D. (2013). Understanding Generation Y and Their Use Of Social Media: A Review And Research Agenda. Journal Of Service Management, 24(3), 245-267.

Capaldo, G., Depolo, M., Rippa, P., \&Schiattone, D. (2017). Supervisor/Peer Involvement In Evaluation Transfer Of Training Process And Results Reliability: A Research In An Italian Public Body. Journal of Workplace Learning, 29 (2), 134-148.

Chauhan, R., Ghosh, P., Rai, A., \& Shukla, D. (2016). The Impact Of Support At The Workplace On Transfer Of Training: A Study Of An Indian Manufacturing Unit. International Journal of Training and Development, 20(3), 200-213.

Chelliah, S., Bujang, T., Lew, T. Y., \& Adriel, K. (2016). Relationship Between Training Components, Work Environment And Participants' Characteristics On Transfer Of Training Skills And Organizational Commitment. International Business Management, 10 (9), $1623-1631$.

Chiaburu, D. S. (2016). Analytics: A Catalyst For Stagnant Science. Journal of Management Inquiry, 25 (1), $111-115$.

Dmytriv, V. (2015). Process of knowledge Preservation And Transfer: Leadership Practices In The Aerospace Industry In Washington State (Doctoral dissertation, University of Phoenix)

Elwyn, G., Frosch, D. L., \&Kobrin, S. (2015). Implementing Shared Decision-Making: Consider All The Consequences. Implementation Science, 11 (1), 114.

Foss, N. J., Pedersen, T., ReinholtFosgaard, M., \&Stea, D. (2015). Why Complementary HRM Practices Impact Performance:The Case Of Rewards, Job Design, And Work Climate In A Knowledge Sharing Context. Human Resource Management, 54 (6), 955-976.

Fang, D., Wu, C., \& Wu, H. (2015). Impact of the Supervisor On Worker Safety Behavior In Construction Projects. Journal of Management in Engineering, 31(6), 112

Geary, J., Aguzzoli, R., \&Lengler, J. (2017). The Transfer of 'International Best Practice'in a Brazilian MNC: A Consideration of the Convergence and Contingency Perspectives. Journal of International Management, 23 (2), 194-207.

Dochy F, Govaerts, N., Kyndt, E., \&Vreye, S. (2017). A Supervisors' Perspective On Their Role In Transfer Of Training. Human Resource Development Quarterly, 28 (4), 515-552.

Hernandez-Sherrington, M. A., Ho, C. T., Roth, M. A., \& Yan, L. (2017). Fiscal Year 2018: The USPTO Congressional Budget Justification. U.S. Patent No. 9,792,351. Washington, DC: U.S. Patent and Trademark Office.

Huang, J. L., Ford, J. K., \& Ryan, A. M. (2017). Ignored No More: Within- Person Variability Enables Better Understanding Of Training Transfer. Personnel Psychology, 70 (3), 557-596.

Hughes, A. (2016). A Meta-Analytic Integration of What Matters in Training Transfer. (Doctoral dissertation, University of Central Florida, Orlando,FL)RetrievedFrom:http://stars.library.ucf.edu/cgi/viewcontent.cgi?article=5972\&context=etd.

Ismail, H. N. (2016). Training And Organizational Commitment: Exploring The Moderating Role Of Goal Orientation In The Lebanese Context. Human Resource Development International, 19 (2), 152-177.

Khulida, K. Y., \& Yean T. F. (2015). Enhancing Career Commitment: The Influence Of Human Resource Management Practices. International Journal of Business and Society, 16(2), 237-246.

Koen, V., Asada, H., Nixon, S., Rahuman, M. H., \&Arif, A. M. (2017). Malaysia's Economic Success Story And Challenges. OECD Economic Department Working Papers, (1369), 1-52. Retrieved From: http://www.oecd.org/fr/concurrence/reforme/Malaysia-s-economic-success-story-and-challenges.pdf.

Lembaga Pertubuhan Peladang (2014). Amanat Ketua Pengarah LPP 2014. Retrieved From: http://www.lpp.gov.my/archive/view/perutusan-dan-amanat-tahun-baru2014-ketua-pengarah-lpp

Lyons, S., \&Kuron, L. (2014). Generational Differences In The Workplace: A Review Of The Evidence And Directions For Future Research. Journal of Organizational Behavior, 35(S1), S139-S157

Massenberg, A. C., Spurk, D., \&Kauffeld, S. (2015). Social Support At The Workplace, Motivation To Transfer And Training Transfer: A Multilevel Indirect Effects Model. International Journal of Training and Development, 19 (3), 161-178.

Mattarelli, E., \&Tagliaventi, M. R. (2015). How Offshore Professionals' Job Dissatisfaction Can Promote Further Offshoring: Organizational Outcomes Of Job Crafting. Journal of Management Studies, 52 (5), 585-620.

Mbachu, C. I., \&Bizien, Q. (2017). Adoption Of Innovation: A Qualitative Research About Employees' Adoption Of Information Technological Tool (ERP) Within An Organization.

Melby-Lervåg, M., Redick, T. S., \& Hulme, C. (2016). Working Memory Training Does Not Improve Performance On Measures Of Intelligence Or Other Measures Of "Far Transfer" Evidence From A Meta-Analytic Review. Perspectives On Psychological Science, 11(4), 512-534

Munro, S. (2017). Factors Influencing Learning Transfer In A Supportive Leadership Development Programmeme (Doctoral Thesis, Victoria, Australia: Deakin University).

Musundire, A. (2015). Effectiveness of the Developmental Supervision Model As A Tool For Improving Quality Of Teaching: Perceptions Of The South African Primary School-Based Managers And Educators (Doctoral dissertation).

Pabon, E., Rodriguez, O., \&Gurin, G. (1992). Clarifying Peer Relations And Delinquency. Youth \& Society, 24 (2), $149-165$.

Pilz, M. (2016). Training patterns of German companies in India, China, Japan and the USA: What Really Works? International Journal for Research in Vocational Education and Training (IJRVET), 3(2), 66-87.

Professional Bulletin. (2017, October 27). Touchpoints 2018 Budget. Retrieved from http://www.bim.org.my/clients/bimorgmy/Downloads/bimnews_602192018121054PM1.pdf.

Sanghi, S. (2016). The Handbook Of Competency Mapping: Understanding, Designing And Implementing Competency Models In Organizations. New Delhi, India: SAGE.

Schindler, L. A., \& Burkholder, G. J. (2016). A Mixed Methods Examination Of The Influence Of Dimensions Of Support On Training Transfer. Journal of Mixed Methods Research, 10 (3), 292-310.

Rani, N., \& Samuel, A. (2016). A Study On Generational Differences In Work Values And Person-Organization Fit And Its Effect On Turnover Intention of Generation $Y$ in India. Management Research Review, 39 (12), 1695-1719.

Vikas, S. (2016). Training and Development in Travel Agencies an Insight into the Current Training Scenario and Developing a Training Manual for TravelAgents.RetrievedFrom:http://ir.inflibnet.ac.in:8080/jspui/bitstream/10603/191287/3/03\%20sona\%20vikas\%20thesis.pdf.

Xiao, J. (1996). The Relationship Between Organizational Factors And The Transfer Of Training In The Electronics Industry in Shenzhen, China. Human Resource Development Quarterly, 7 (1), 55-73. 